\title{
UTANG PIUTANG SETELAH TERJADINYA PERCERAIAN
}

\author{
Wayan Resmini'1), Abdul Sakban'1), Ni Putu Ade Resmayani²) \\ 1)Program Studi PPKn, FKIP, Universitas Muhammadiyah Mataram, Mataram, NTB, Indonesia \\ 2) Program Studi PPKn, FKIP, Universitas Muhammadiyah Mataram, Mataram, NTB, Indonesia \\ 3)Program Studi Pariwisata, Sekolah Tinggi Pariwisata Mataram, Mataram, NTB, Indonesia \\ Corresponding author: Ni Putu Ade Resmayani \\ E-mail: aderesmayani@gmil.com
}

\section{Diterima 19 Oktober 2021, Direvisi 11 November 2021, Disetujui 11 November 2021}

\begin{abstract}
ABSTRAK
Perkawinan adalah ikatan sebagai suami istri dengan tujuan membentuk keluarga yang bahagia dan kekal. Sayangnya, ikatan tersebut kerap berujung pada perceraian. Tanggung jawab suami dan istri terhadap utang piutang bersama setelah terjadinya perceraian dibedakan menjadi dua, yaitu utang pribadi dan utang persatuan. Berkaitan dengan hal tersebut, perlu dilaksanakan penyuluhan untuk memberikan pemahaman dan pendidikan bagi masyarakat yang akan melakukan perceraian terutama dalam masalah hukum yuridis utang piutang. Lokasi kegiatan adalah di kecamatan Sekarbele, Kota Mataram. Metode yang dipergunakan dalam kegiatan ini adalah ceramah dan tanya jawab. Dari hasil diskusi, diketahui bahwa Masyarakat Kecamatan Sekarbela belum mengerti dengan masalah tersebut karena belum pernah adanya sosialisasi dari pemerintah terkait. Umumnya, apabila terjadi perceraian, pihak perempuan tidak terlalu memikirkan hak - hak mereka. Begitu ada putusan perceraian, mereka pulang ke rumah orang tuanya dengan membawa apa yang bisa mereka bawa (pakaian dan perabot rumah tangga). Hal ini disebabkan karena masyarakatnya masih sangat sederhana kehidupannya. Disamping itu, pengaruh sistem kekerabatan patrilinial turut berperan dalam permasalahan ini. Jika pihak perempuannya yang menyebabkan terjadinya utang, maka keluarga pihak laki-laki (suaminya) yang menanggung utang tersebut dengan menceraikan istrinya (dengan kesepakatan), sebaliknya kalau yang membuat utang suami jelas itu adalah tanggung jawab sang suami.
\end{abstract}

Kata Kunci: utang; piutang; perceraian

\begin{abstract}
Marriage is a bond between husband and wife to form a happy and eternal family. Unfortunately, these bonds often lead to divorce. The responsibility of husband and wife for joint debts after the divorce is divided into two, namely personal loan and union loan. In this regard, it is necessary to conduct counseling to provide understanding and education for people going to divorce, especially in legal matters of debt and debt juridical. The location of the activity is in the Sekarbele sub-district, Mataram City. The method used in this activity is lecture, question, and answer. The discussion results show that the people of Sekarbela District do not understand this problem because there has never been any socialization from the government. Generally, when a divorce occurs, the women do not think about their rights. Once a divorce verdict happens, they return to their parents' house with what they can bring (clothes and some household furniture). This situation occurs because the people are still naive in doing their life. In addition, the influence of the patrilineal kinship system also plays a role in this problem. If the woman causes the debt, then the man's family (husband) bears the debt by divorcing his wife (by agreement). On the other hand, it is the husband's responsibility if the husband makes the debt clear.
\end{abstract}

Keywords: debt; receivable; divorce

\section{PENDAHULUAN}

Perkawinan adalah hubungan hukum yang merupakan pertalian yang sah antara seorang laki-laki dan seorang wanita yang telah memenuhi syarat-syarat perkawinan. Berdasarkan Pasal 7 ayat (1) Undang-Undang Nomor 16 Tahun 2019 merupakan penyempurnaan Undang Undang No I Tahun 1974 tentang Perkawinan, menyebutkan perkawinan hanya diizinkan apabila pria dan wanita sudah 19 tahun tahun, UU Perkawinan tetap mengatur izin pernikahan di bawah usia 19 tahun jika kedua orang tua calon mempelai meminta dispensasi kepada Pengadilan. pengertian perkawinan adalah suatu ikatan lahir batin antara seorang pria dengan wanita sebagai suami istri dengan tujuan membentuk keluarga (rumah tangga) yang bahagia dan kekal berdasarkan Ketuhanan Yang Maha Esa. Perkawinan yang bertujuan untuk membentuk 
keluarga yang bahagia dan kekal, dapat diartikan bahwa perkawinan itu haruslah berlangsung seumur hidup dan tidak boleh putus begitu saja. Sedangkan menurut Kompilasi Hukum Islam (selanjutnya disebut $\mathrm{KHI}$, perkawinan adalah pernikahan, yaitu akad yang sangat kuat atau miitsaaqan ghalizhan untuk menaati perintah Allah dan melaksanakannya merupakan ibadah, dengan tujuan untuk mewujudkan kehidupan rumah tangga yang sakinah, mawaddah, warahmah sebagai suatu keluarga.

Bagi masyarakat Indonesia, sudah menjadi pegangan hidup mereka sejak lama bahwa mengenai perkawinan, kelahiran, dan kematian adalah sangat dipengaruhi oleh ketentuan-ketentuan agama. Orang yang taat pada agamanya tidak mudah berbuat sesuatu yang melanggar larangan agama dan kepercayaannya. Selain larangan-larangan, agama juga mempunyai peraturan-peraturan yang memuat perintah-perintah yang wajib dan harus ditaati. Apabila terjadi suatu perkawinan, maka timbulah hak dan kewajiban antara suami-istri secara timbal balik, demikian juga akan timbul hak dan kewajiban antara orang tua dan anak secara timbal balik serta hak dan kewajiban terhadap harta bersama.

Dalam suatu perkawinan, salah satu yang menjadi masalah yang menakutkan adalah perceraian. Seorang suami yang akan menceraikan istrinya mengajukan permohonan kepada Pengadilan untuk mengadakan sidang guna menyaksikan ikrar talak di Pengadilan tempat kediaman termohon (istri).

Salah satu hal yang sering menjadi perbincangan dalam rumah tangga adalah masalah kepemilikan harta. Harta milik suami, harta milik istri, dan harta milik bersama. Biasanya urusan tersebut menjadi pembicaraan hangat dan serius ketika terjadi keretakan hubungan suami istri dan berujung kepada perceraian. Urusan kepemilikan yang pada awal rumah tangga dibangun tidak atau jarang diperhitungkan karena indahnya cinta, nikmatnya hubungan cinta yang dihalalkan dengan pernikahan, atau karena ketabuan membicarakannya, justru seringkali menjadi penyebab bertambah parahnya keadaan rumah tangga yang sedang berada di ambang perceraian, terkadang urusan gono-gini juga menjadi penyebab sengketa ahli waris ketika perpisahan antara suami istri disebabkan karena salah satu di antara mereka meninggal dunia.

Akan tetapi dalam perkara ini adalah peruntukannya yaitu untuk memenuhi kebutuhan dan kepentingan keluarga, dan hal ini diakui serta dinyatakan telah terbukti, oleh karena itu hutang tersebut menjadi tanggung jawab harta bersama. Perjanjian hutang dalam rumah tangga sering dilakukan oleh suami istri untuk memenuhi kebutuhan keluarga maupun untuk modal suatu usaha dan ini bukanlah suatu hal yang buruk. Akan menjadi memalukan apabila tidak sanggup untuk membayar kembali hutang-hutang tersebut sehingga menimbulkan permasalahan terhadap pihak ketiga yang hak-haknya harus dilindungi, oleh karena itu perlu penyelesaian yang tepat dan adil bagi para pihak.

Untuk melakukan perjanjian hutang dalam rumah tangga selain harus memperhatikan hukum tentang perjanjian secara umum yang diatur dalarn Pasal 1320 KUHPerdata, juga harus memperhatikan hak dan kewajiban suami istri dalam rumah tangga bahwa suami atau istri tanpa persetujuan pihak lain tidak diperbolehkan menjual atau memindahkan harta bersama ataupun melakukan perbuatan hukum lainnya sebagaimana yang diatur oleh Pasal 36 ayat (1) Undang-Undang Perkawinan. Masalah yang sering terjadi dalam masyarakat adalah adanya utang bersama setelah terjadinya perceraian.

Daerah Provinsi Nusa tenggara Barat sebagai salah satu daerah yang ada di wilayah Indonesia dan memiliki sepuluh daerah kabupaten dan dua kota., Kecamatan Sekarbele, Kota Mataram, tentunya aktivitas masyarakatnya dalam usaha meningkatkan taraf hidupnya, membuka akses informasi guna meningkatkan taraf hidup dalam rangka pembangunan nasional, terutama yang berhubungan dengan kesejahteraan dan rasa aman pada dirinya untuk dapat melakukan aktivitasnya guna menambah wawasan dan daya tahan diri terhadap lingkungan keluarga dan lingkungan di sekitarnya. sehubungan dengan hal itu, maka masyarakat perlu diberikan informasi tentang segala sesuatu yang berhubungan dengan masalah hutang bersama setelah terjadinya terceraian.

\section{METODE}

Pelaksanaan pengabdian masyarakat lokasinya di Kecamatan Sekarbele, Kota Mataram. penyuluhan tentang hutang piutang setelah terjadinya perceraian diadakan oleh Tim pengabdian masyarakat Program Studi PPKn FKIP Universitas Muhammadiyah dengan melibatkan juga Tim pengabdian Sekolah Tinggi Pariwisata Mataram dan kantor Kecamatan Sekarbela. Penyuluhan ini dilaksanakan secara langsung dengan memperhatikan peraturan kesehatan ( $3 \mathrm{M}$ yaitu mempergunakan masker, mengatur jarak dan mencuci tangan), dengan jumlah subyek 20 orang terdiri dari pegawai kecamatan, lurah, kepala lingkungan dan perwakilan masyarakan, 
mereka diharapkan dapat memberikan informasi lebih lanjut kepada masyarakat.Adapun metode kegiatan mempergunakan metode ceramah untuk menjelaskan materi, dan dilanjutkan dengan metode tanya jawab.

\section{HASIL PEMBAHASAN \\ Pengertian Perceraian}

Pengertian Perceraian adalah cerai hidup atau perpisahan hidup antara pasangan suami istri sebagai akibat dari kegagalan mereka menjalankan peran masing-masing. Dalam hal ini perceraian dilihat sebagai akhir dari suatu ketidakstabilan perkawinan dimana pasangan suami istri kemudian hidup terpisah dan secara resmi diakui oleh hukum yang berlaku (Anshary, 2099: 45). Perceraian merupakan terputusnya keluarga karena salah satu atau kedua pasangan memutuskan untuk saling meninggalkan sehingga mereka berhenti melakukan kewajibannya sebagai suami istri. Perceraian menurut UU perkawinan merupakan perceraian terjadi apabila kedua belah pihak baik suami maupun istri sudah sama-sama merasakan ketidakcocokan dalam menjalani rumah tangga. Pasal 39 ayat (2) UU Perkawinan serta penjelasannya secara jelas menyatakan bahwa perceraian dapat dilakukan apabila sesuai dengan alasan-alasan yang telah ditentukan. Definisi perceraian di Pengadilan Negeri itu, dilihat dari putusnya perkawinan. Putusnya perkawinan di UUP dijelaskan, yaitu: karena kematian, karena perceraian dan karena putusnya pengadilan.

\section{Kondisi Menjelang Perceraian}

Situasi dan kondisi menjelang perceraian yang diawali dengan proses negosiasi antara pasangan suami istri yang berakibat pasangan tersebut sudah tidak bisa lagi menghasilkan kesepakatan yang dapat memuaskan masing-masing pihak. Mereka seolah-olah tidak dapat lagi mencari jalan keluar yang baik bagi mereka berdua. Perasaan tersebut kemudian menimbulkan permusuhan dan kebencian diantara kedua belah pihak yang membuat hubungan antara suami istri menjadi semakin jauh.

\section{Faktor-faktor Yang Menyebabkan Perceraian}

Di dalam sebuah perceraian banyak faktor-faktor atau penyebab terjadinya perceraian itu sendiri. Beberapa faktor atau penyebab terjadinya perceraian, diantaranya :

1. Ketidakharmonisan dalam rumah tangga : Alasan tersebut di atas adalah alasan yang paling kerap dikemukakan oleh pasangan suami - istri yang akan bercerai. Ketidakharmonisan bisa disebabkan oleh berbagai hal antara lain, krisis keuangan, krisis akhlak, dan adanya orang ketiga. Dengan kata lain, istilah keharmonisan adalah terlalu umum sehingga memerlukan perincian yang lebih mendetail.

2. Gagal komunikasi : Komunikasi merupakan hal terpenting dalam menjalin hubungan. Jika Anda dan pasangan kurang berkomunikasi atau tidak cocok dalam masalah ini, maka dapat menyebabkan kurangnya rasa pengertian dan memicu pertengkaran. Jika komunikasi Anda dan pasangan tidak diperbaiki, bukan tidak mungkin akan berujung pada perceraian.

3. Perselingkuhan : Selingkuh merupakan penyebab lainnya perceraian. Sebelum melangkah ke jenjang Perkawinan, ada baiknya Anda dan pasangan memegang kuat komitmen dan menjaga keharmonisan hubungan.

4. Kekerasan dalam rumah tangga (KDRT) : KDRT tidak hanya meninggalkan luka di fisik tetapi juga psikis. Oleh karena itu kenalilah pasangan Anda sebaik mungkin sebelum memutuskan menikah dengannya. Jangan malu untuk melaporkan KDRT yang Anda alami pada orang terdekat atau lembaga perlindungan.

5. Krisis moral dan akhlak : Selain hal diatas, perceraian juga sering dilandasi krisis moral dan akhlak, yang dapat dilalaikannya tanggung jawab baik oleh suami ataupun istri, poligami yang tidak sehat, dan keburukan perilaku lainnya yang dilakukan baik oleh suami ataupun istri, misal mabuk, terlibat tindak kriminal.

6. Perzinahan : Di samping itu, masalah lain yang dapat mengakibatkan terjadinya perceraian adalah perzinahan, yaitu hubungan seksual di luar nikah yang dilakukan baik oleh suami maupun istri.

7. Perkawinan tanpa cinta: Untuk kasus yang satu ini biasanya terjadi karena faktor tuntutan orang tua yang mengharuskan anaknya menikah dengan pasangan yang sudah ditentukan, sehingga setelah menjalani bahtera rumah tangga sering kali pasangan tersebut tidak mengalami kecocokan. Selain itu, alasan inilah yang kerap dikemukakan oleh suami dan istri, untuk mengakhiri sebuah perkawinan yakni bahwa perkawinan 
mereka telah berlangsung tanpa dilandasi adanya cinta. Untuk mengatasi kesulitan akibat sebuah Perkawinan tanpa cinta, pasangan harus merefleksi diri untuk memahami masalah sebenarnya, juga harus berupaya untuk mencoba menciptakan kerjasama dalam menghasilkan keputusan yang terbaik.

8. Perkawinan dini : Menikah di usia muda lebih rentan dalam hal perceraian. Hal ini karena pasangan muda belum siap menghadapi berbagai kesulitan dalam kehidupan Perkawinan dan ego masing-masing yang masih tinggi.

9. Masalah ekonomi : Tingkat kebutuhan ekonomi di jaman sekarang ini memaksa kedua pasangan harus bekerja untuk memenuhi kebutuhan ekonomi keluarga, sehingga seringkali perbedaan dalam pendapatan atau gaji membuat tiap pasangan berselisih, terlebih apabila sang suami yang tidak memiliki pekerjaan yang menyebabkan pasangan dianggap tidak mampu memenuhi kebutuhan materi keluarga, sehingga memutuskan untuk meninggalkannya.

10. Perubahan budaya Zaman semakin modern, jika dahulu perceraian dianggap hal yang tabu sekarang ini telah menjadi tren dan gaya hidup banyak pasangan.

11. Adanya masalah-masalah dalam perkawinan: Dalam sebuah perkawinan pasti tidak akan lepas dari yang namanya masalah. Masalah dalam perkawinan itu merupakan suatu hal yang biasa. tapi percekcokan yang berlarut-larut dan tidak dapat didamaikan lagi secara otomatis akan disusul dengan pisah ranjang.

12. Keturunan : Anak memang menjadi impian bagi tiap pasangan, tetapi tidak semua pasangan mampu memberikan keturunan, salah satu penyebabnya mungkin kemandulan pada salah satu pasangan tersebut, sehingga menjadikan sebuah rumah tangga menjadi tidak harmonis (Anshary, 2019: 54).

\section{Pengaruh Perceraian}

Menurut Anshary (2019: 54), perceraian tidak selalu negatif namun juga bukan suatu hal yang positif. Perceraian dapat menimbulkan dampak-dampak yang ditimbulkannya, diantaranya sebagai berikut:

1. Anak menjadi korban

Anak merupakan korban yang paling terluka ketika orang tuanya memutuskan untuk bercerai. Anak dapat merasa ketakutan karena kehilangan sosok ayah atau ibu mereka, takut kehilangan kasih sayang orang tua yang kini tidak tinggal serumah. Mungkin juga mereka merasa bersalah dan menganggap diri mereka sebagai penyebabnya. Prestasi anak di sekolah akan menurun atau mereka jadi lebih sering untuk menyendiri. Anak-anak yang sedikit lebih besar bisa pula merasa terjepit di antara ayah dan ibu mereka. Salah satu atau kedua orang tua yang telah berpisah mungkin menaruh curiga bahwa mantan pasangan hidupnya tersebut mempengaruhi sang anak agar membencinya. Ini dapat membuat anak menjadi serba salah, sehingga mereka tidak terbuka termasuk dalam masalah-masalah besar yang dihadapi ketika mereka remaja. Sebagai pelarian yang buruk, anak-anak bisa terlibat dalam pergaulan yang buruk, narkoba, atau hal negatif lain yang bisa merugikan.

2. Dampak untuk orang tua

Selain anak-anak, orang tua dari pasangan yang bercerai juga mungkin terkena imbas dari keputusan untuk bercerai. Sebagai orang tua, mereka dapat saja merasa takut anak mereka yang bercerai akan menderita karena perceraian ini atau merasa risih dengan pergunjingan orang-orang. Beberapa orang tua dari pasangan yang bercerai akhirnya harus membantu membesarkan cucu mereka karena ketidaksanggupan dari pasangan yang bercerai untuk memenuhi kebutuhan anak-anaknya.

3. Bencana keuangan

Jika sebelum bercerai, suami sebagai pencari nafkah maka setelah bercerai Anda tidak akan memiliki pendapatan sama sekali apalagi jika mantan pasangan Anda tidak memberikan tunjangan. Atau jika pemasukan, berasal dari Anda dan pasangan, sekarang setelah bercerai, pemasukan uang Anda berkurang. Jika Anda mendapat hak asuh atas anak, berarti Anda juga bertanggung jawab untuk menanggung biaya hidup dari anak Anda. Yang perlu diingat, setelah bercerai, umumnya banyak keluarga mengalami penurunan standar kehidupan hingga lebih dari 50 persen.

4. Masalah pengasuhan anak 
Setelah bercerai, berarti kini Anda harus menjalankan peranan ganda sebagai ayah dan juga sebagai ibu. Ini bukanlah hal yang mudah karena ada banyak hal lain yang harus Anda pikirkan seorang diri. Terlebih, jika anak sudah memasuki masa remaja yang penuh tantangan, Anda harus dengan masuk akal menjaga atau memberikan disiplin kepada anak agar dapat tumbuh menjadi anak yang baik. Masalah lain dalam hal pengasuhan anak adalah ketika harus berbagi hak asuh anak dengan pasangan karena bisa jadi Anda masih merasa sakit hati dengan perlakuan mantan Anda sehingga sulit untuk bersikap adil. Halhal yang harus dibicarakan seperti pendidikan atau disiplin anak mungkin dapat menyebabkan pertengkaran karena tidak sepaham dan rasa sakit hati dapat membuat hal ini semakin buruk.

5. Gangguan emosi

Adalah hal yang wajar jika setelah bercerai Anda masih menyimpan perasan cinta terhadap mantan pasangan Anda. Harapan Anda untuk hidup sampai tua bersama pasangan menjadi kandas, ini dapat menyebabkan perasaan kecewa yang sangat besar yang menyakitkan. Mungkin juga Anda ketakutan jika tidak ada orang yang akan mencintai Anda lagi atau perasaan takut ditinggalkan lagi di kemudian hari. Perasaan lain yang mungkin dialami adalah perasaan terhina atau perasaan marah dan kesal akibat sikap buruk pasangan. Anda juga mungkin merasa kesepian karena sudah tidak ada lagi tempat Anda berbagi cerita, tempat Anda mencurahkan dan mendapatkan bentuk kasih sayang. Serangkaian problem kesehatan juga bisa disebabkan akibat depresi karena bercerai.

6. Bahaya masa remaja kedua

Pasangan yang baru bercerai sering mengalami masa remaja kedua. Mereka mencicipi kemerdekaan baru dengan memburu serangkaian hubungan asmara dengan tujuan untuk menaikkan harga diri yang jatuh atau untuk mengusir kesepian. Hal ini bisa menimbulkan problem baru yang lebih buruk dan tragis karena tidak mempertimbangkan baik-baik langkah yang dilakukan.

\section{Cara-cara yang dapat dilakukan untuk} Mengurangi Perceraian

Menurut Hilman Hadikusumo (2013: 34), beberapa cara yang dapat dipertimbangkan, saat rumah tangga berada diambang perceraian. Berikut adalah beberapa diantaranya:

1. Cari Sumbernya

Ada asap pasti ada api. Demikian juga halnya dengan kehidupan rumah tangga. Keputusan untuk bercerai tentunya bukan tanpa sebab. Karena itu, carilah sumber dari hal ini. Jika sumber permasalahannya sudah dapat ditemukan, cobalah untuk menyelesaikan dengan baik-baik. Sebab setiap masalah tentu mempunyai jalan keluar. Apapun masalah yang menjadi sumber dari keputusan cerai yang akan diambil, sebaiknya pertimbangkan dengan matang. Sebab, jika kita sudah menemukan sumber permasalahannya, maka keputusan yang tepat akan dapat diambil, apakah akan meneruskan keputusan untuk bercerai, atau tidak.

2. Introspeksi

Bila Anda sudah mengetahui penyebab kenapa Anda atau suami ingin bercerai, cobalah untuk berintropeksi. Ini yang seringkali sulit dilakukan. Pasalnya, masing-masing pasangan pasti merasa dirinyalah yang benar. Mereka tak bakal bisa menerima kenyataan bahwa merekalah pangkal sebab munculnya niat cerai. Mungkin, Anda malu mengakui secara jujur kekurangan Anda, tapi cobalah menjawab dengan jujur pada diri sendiri bahwa yang dikatakan pasangan Anda ada benarnya. Mumpung masih ada waktu, kenapa tak Anda coba perbaiki dari sekarang? Tentu, suami pun harus melakukan hal serupa. Bisa jadi, ialah yang membuat perkawinan menjadi goyah dan tak harmonis lagi.

3. Jangan membesarkan masalah

Jika Anda dan suami sudah tahu sumber keributan dan konflik dalam rumah tangga, sebaiknya jangan memperbesar masalah. Juga, jangan mencari masalah baru. Pasalnya, ini justru akan memperkeruh suasana. Bila Anda menyadari kekurangan yang ada, tak ada salahnya meminta maaf. Tidak perlu malu dan berusaha menjadi istri yang baik seperti yang diharapkan suami. cobalah untuk mencari solusi sebaik-baiknya. 
4. Pisah sementara

Meski sepertinya sangat tak enak, cara ini bisa menjadi jalan terbaik untuk menghindari perceraian. Pisah untuk sementara waktu akan membantu suami-istri untuk menenteramkan diri sekaligus menilai, keputusan apa yang sebaiknya ditempuh. Kenapa harus pisah rumah? Pasalnya, dug hati yang sama-sama sedang panas, sebaiknya tak bertemu setiap hari. Jika setiap hari bertemu, yang terjadi bukan membaik, malah justru bakal semakin panas. Bisa-bisa ribut terus dan tidak ada titik temu. Yang dibahas setiap hari pasti akan batik ke masalah yang itu-Itu saja. Anda bisa misalnya "mengungsi" dulu ke rumah orang tua, sementara suami pindah dulu sementara kerumah orang tuanya. Pisah rumah akan membantu mendinginkan hati yang sedang memanas, sehingga Anda dan suami dapat berpikir jernih.

5. Komunikasi

Apapun, komunikasi merupakan fondasi sebuah hubungan, termasuk hubungan dalam perkawinan. Tanga komunikasi, hubungan tak bakal bisa bertahan. Jadi, seberat apapun situasi yang tengah Anda hadapi, sebaiknya tetap lakukan komunikasi dengan pasangan. Bahkan setelah Anda dan suami sama-sama hidup terpisah, cobalah untuk tetap berkomunikasi. Coba diskusikan bersama, langkah terbaik apa yang bisa Anda berdua lakukan untuk menghindari perceraian, untuk mempertahankan mahligai rumahtangga. Tak mudah memang, tapi jika Anda berdua sudah berpisah untuk sementara waktu, situasi panas barangkali sudah lewat, sehingga Anda berdua sudah siap untuk berkomunikasi. Jangan merasa malu atau gengsi untuk saling menghubungi.

6. Libatkan keluarga

Jika kenyataannya, pasangan sudah tidak dapat diajak berkomunikasi atau selalu berusaha menghindar, cobalah libatkan anggota keluarga yang memang dekat dengannya. Orang tua, kakak atau pamannya misalnya. Pokoknya, siapa saja yang Anda rasa bisa Anda ajak berbicara. Tentu, Anda jangan pernah menutupi akar permasalahan yang ada kepada mereka, tetapi berterus teranglah. Katakan juga, apa sebetulnya kekurangan Anda maupun kekurangan suami. Siapa tahu, mediator ini dapat melunakkan hati Anda dan pasangan, sekaligus mencarikan solusi untuk kembali bersatu.

7. Cari teman curhat

Menghadapi perceraian tentu akan membuat pikiran runyam, pekedaan terbengkalai dan bingung harus berbuat apa. Nah, kondisi tidak nyaman ini bisa Anda atasi bila Anda bisa berbagi dengan orang terdekat, sahabat misalnya. Dengan berbagi, beban pikiran Anda akan terasa lebih ringan. Yang harus dicermati, jangan mencari teman curhat yang lawan jenis. Carilah teman curhat sesama jenis. Pasalnya, bila Anda bercerita, mengungkapkan uneg-uneg Anda pada teman pria, belum tentu sepenuhnya ia akan mendukung Anda untuk kembali bersatu dengan suami. Bisa jadi ia malah menggoda Anda, dan jika Anda akhirnya benar-benar tergoda, yang muncul akhirnya malah masalah baru.

8. Ingat anak

Anak biasanya menjadi senjata terampuh untuk meredam konflik antara suami-istri. Jadi, bila ternyata antara Anda dan suami sama-sama menginginkan perceraian, cobalah ingat anak-anak Anda, buah cinta kasih Anda dan suami. Ingatlah bahwa mereka masih sangat membutuhkan Anda dan suami. Apakah mereka harus menjadi korban perceraian karena keegoisan orang tuanya? Lantas, setelah Anda bercerai, kemana dan kepada siapa mereka harus ikut, Anda atau suami? Jika Anda menyayangi mereka, pikirkan kembali keputusan tersebut.

9. Kesampingkan ego pribadi

Jika Anda memang masih menginginkan keutuhan rumahtangga, segera buang jauh-jauh ego yang ada dalam diri Anda. Jangan merasa diri selalu benar dan selalu menyudutkan pasangan, begitu pula sebaiknya. Sadarilah bahwa apa yang terajadi sekarang adalah kesalahan Anda dan suami. Kalaupun selama ini ada sakit hati yang terselip, cobalah untuk saling memberi maaf.

10. Jujur pada diri sendiri Jujurlah pada diri sendiri, apakah Anda sudah siap mental untuk berpisah selamanya dengan suami? Perceraian tidaklah semudah yang dibayangkan. Berpisah lalu hidup tenang. Tidak selamanya perceraian membuat 
kehidupan menjadi bahagia. Bisa jadi justru sebaliknya, lebih hancur. Banyak masalah-masalah di kemudian hari yang berbuntut panjang. Mulai anak, harta gono-gini sampai hubungan antar-keluarga yang ikut tidak harmonis. Jadi, pikirkan kembali jika ingin mengambil keputusan ini. Selain jujur, Anda juga harus mengedepankan rasio. Perempuan biasanya memang lebih banyak menggunakan perasaan, namun untuk soal seberat ini jangan hanya perasaan. Pertimbangkan benar, apa dampaknya bagi Anda dan keluarga jika perceraian itu benar-benar terjadi.

11. Banyak berdoa

Banyak berdoa dan mendekatkan diri pada Yang Maha Kuasa dapat membantu permasalahan Anda. Mintalah petunjuk dari-Nya. Dengan semakin bertekun dan mendekat kan diri, insya Allah doa Anda akan terjawab

12. Buka lembaran baru

Jika Anda dan suami akhinya bisa kembali rukun, maka Anda harus siap membuka lembaran baru bersama suami. Jangan pernah mengungkitungkit persoalan dan penyebab Anda berdua pernah berniat untuk bercerai. Sekali Anda mengungkit-ungkit, bisa jadi Anda akhirnya akan benar-benar bercerai. Yang paling penting adalah saling mengingatkan dan memperbaiki kekurangan-kekurangan yang ada.

\section{Tanggung Jawab hutang piutang setelah terjadinya Perceraian}

Pengertian utang dalam arti sempit adalah suatu kewajiban yang timbul hanya dari adanya perjanjian utang-piutang sedangkan pengertian uutang dalam arti luas adalah seluruh kewajiban yang ada dalam suatu perikatan baik yang timbul karena undangundang maupun yang timbul karena adanya perjanjian umpamanya antara lain kewajiban menyerahkan sesuatu, kewajiban untuk berbuat sesuatu dan tidak berbuat sesuatu Namun demikian hal ini diharapkan tidak terjadi lagi karena dalam Undang-Undang Kepailitan yang baru, yaitu Undang Undang No. 37 Tahun 2004 tentang Kepailitan, Pasal 1 ayat (6) telah diberikan definisi yang tegas terhadap pengertian utang, yaitu: "kewajiban yang dinyatakan atau dapat dinyatakan dalam jumlah uang baik dalam mata uang Indonesia maupun mata uang asing, baik secara langsung maupun yang akan timbul dikemudian hari atau kontinjen, yang timbul karena perjanjian atau
Undang-Undang dan wajib dipenuhi oleh debitor dan bila tidak dipenuhi memberi hak kepada kreditor untuk mendapat pemenuhannya dari harta kekayaan debitor"

Pengertian utang adalah kewajiban yang dinyatakan dalam jumlah uang baik secara langsung maupun yang akan timbul di kemudian hari (kontinjen), yang timbul karena perjanjian atau UU yang wajib dipenuhi oleh debitor dan bila tidak akan dikenakan sanksi.

$$
\text { Harta bersama merupakan }
$$

konsekuensi hukum dari perkawinan. Menurut Pasal 35 ayat (1) UUP, harta benda yang diperoleh selama perkawinan menjadi harta bersama. Ini berarti harta bersama mutlak ada dan tak boleh ditiadakan oleh para pihak. Sumber dari harta bersama perkawinan adalah peroleh selama perkawinan. Ahli lain mengungkapkan bahwa Harta bersama (gonogini) adalah harta benda atau hasil kekayaan yang diperoleh selama berlangsungnya perkawinan. Harta bersama dapat berupa benda berwujud, benda tidak berwujud (hak dan kewajiban), benda bergerak, benda tidak bergerak dan surat-surat berharga. Sepanjang tidak diatur lain dalam perjanjian perkawinan, apabila terjadi perceraian, maka masingmasing pihak istri maupun suami berhak atas separoh (seperdua) dari harta bersama (Hilman Hadikusuma, 2013: 65).

Sejak mulai perkawinan terjadi, suatu percampuran antara kekayaan suami dan kekayaan istri, jikalau tidak diadakan perjanjian apa-apa keadaan yang demikian itu berlangsung seterusnya dan tak dapat diubah lagi selama perkawinan. Percampuran kekayaan, adalah mengenai seluruh aktiva dan passiva baik yang dibawah oleh masing-masing pihak ke dalam perkawinan maupun yang akan diperoelh di kemudian hari selama perkawinan. Kekayaan bersama itu oleh undang-undang dinamakan "gemeenshapp".

Sedangkan yang dimaksud dengan harta yang diperoleh selama perkawinan adalah harta benda yang diperoleh disini harus ditafsirkan sebagai hasil kerjasama mereka. Kata kerjasama disini harus ditafsirkan longgar, sehingga tidak dimaksudkan adanya kerjasama secara fisik. Dalam pengertian ini, apabila harta kekayaan itu diperoleh oleh seorang diantara mereka, misalnya gaji suami, dipandang sebagai hasil kerjasama meskipun secara fisik tidak ada kerjasama di sana. Seorang suami bekerja tentu atas persiapan yang dilakukan istri sebagai ibu rumah tangga (,http://Pendidikan blogspot co.id/2021/05/Pencatatan- - Perkawinan dan akta - nikah. Html (08/05/21).

Hak mengurus kekayaan bersama 
berada di tangan suami, yang dalam hal ini mempunyai kekuasaan yang sangat luas. Selain pengurusan itu tak bertanggung jawab kepada siapaun juga, pembatasan terhadap kekuasaannya hanya terletak dalam larangan untuk membereikan dengan percuma bendabenda yang tak bergerak atau seluruh atau sebagian dari semua benda-benda yang bergerak kepada orang lain kepada anaknya sendiri yang lahir dari perkawinan itu (Pasal 124 ayat ( 3$)$.

\section{a. Pembagian Harta Bersama}

Pembagian harta bersama termasuk masalah yang cukup rumit dipecahkan dalam sebuah perkawinan yang berujung pada perceraian. Hal ini cenderung menimbulkan perselisihan yang berkepanjangan, khusus dalam kasus cerai hidup dimana proses persidangannya di Pengadilan Agama membutuhkan waktu yang cukup lama, bahkan terkadang hingga melalui semua tingkat peradilan yang tentu saja tidak lagi efisien dari segi waktu dan biaya yang harus dikeluarkan oleh para pihak Perjanjian perkawinan ini sangat bermanfaat dalam rangka mengefisienkan waktu dan menghemat biaya bagi mereka yang bersengketa, karena sebelum dilangsungkan perkawinan para pihak telah mengadakan perjanjian perkawinan, maka putusan sengketa tentang harta bersama akan mengacu kepada perjanjian yang mereka buat.

Ketentuan tentang pembagian harta bersama didasarkan pada kondisi yang menyertai suatu hubungan perkawinan, seperti kematian, perceraian atau pembagian harta bersama karena adanya perkawinan poligami.

Mengenai besarnya bagian masingmasing suami istri dari harta bersama diatur di dalam pada Pasal 37 Undang-Undang Perkawinan dimana dikatakan bahwa bila perkawinan putus karena perceraian, harta bersama diatur menurut hukumnya masingmasing. Dalam penjelasan pasal tersebut dijelaskan bahwa yang dimaksud dengan hukumnya masing-masing ialah hukum agama, hukum adat dan hukum-hukum lainnya.

Pasal 96 ayat (1) KHI diatur bahwa, apabila terjadi cerai mati, maka separuh harta bersama menjadi hak pasangan yang hidup lebih lama, akan tetapi sebelum dibaginya harta bersama semua yang menjadi beban atau tanggungan dari orang yang meninggal baik itu istri atau suami dikeluarkan terlebih dahulu agar tidak menggangu hak dari para ahli waris.Pembagian harta bersama perlu didasarkan pada aspek keadilan untuk semua pihak yang terkait. Keadilan yang dimaksud mencakup pada pengertian bahwa pembagian tersebut tidak mendiskriminasikan salah satu pihak, kepentingan masing-masing pihak perlu diakomodasi asalkan sesuai dengan kenyataan yang sesungguhnya.

Menurut pendapat Hilman Hadikusumo (2018: 54), tentang pengaturan harta bersama jika perkawinan putus karena perceraian harta bersama diatur menurut hukum masingmasing,misalnya:

1. Daerah hukum adat Jawa Tengah dibagi dalam segendong sepikul. Akan tetapi sekarang telah berubah menjadi setengah-setengah.

2. Di daerah hukum Jawa Barat besarnya bagian antara suami dan istri harus seimbang dengan banyaknya tenaga yang dicurahkan dalam usaha mencari nafkah selama perkawinan.

3. Bagi mereka yang tunduk pada BW, maka harta bersama dibagi antara suami dan istri setengah-setengah.

Sedangkan Pasal 128 BW mengatur bahwa "Setelah bubarnya persatuan, maka harta benda kesatuan dibagi dua antara suami istri, atau antara para ahli waris mereka masingmasing, dengan tidak memperhatikan soal dari pihak yang manakah barang-barang itu diperolehnya".Sementara itu, harta bawaan dan harta perolehan tetap otomatis menjadi hak milik pribadi masing-masing yang tidak perlu dibagi secara bersama. Berdasarkan ketentuan tersebut, jika pasangan suami istri bercerai, harta bersama mereka dibagi dua (50:50).

\section{b. Kedudukan hutang Sebagai Harta Benda Dalam Perkawinan}

Harta benda dapat memenuhi kebutuhan pokok dan kebutuhan penunjang hidup manusia. Dengan adanya harta benda berbagai kebutuhan hidup seperti makanan, pakaian, tempat tinggal, penunjang beribadah dan sebagainya dapat dipenuhi. Dalam perkawinan kedudukan harta benda sebagai harta keluarga disamping sarana untuk memenuhi kebutuhan tersebut di atas, juga berfungsi sebagai pengikat perkawinan. Perlu dipahami bahwa harta benda dalam perkawinan adalah harta serikat atau syrkah. Oleh sebab itu penggunaan harta harus menurut aturan yang telah ada agar menjadi halal, bermanfaat dan mengandung berkah. Dalam perkawinan sering terdapat dua jenis harta benda, yaitu harta benda yang dibawa dari luar perkwinan yang telah ada pada saat perkawinan dilaksanakan dan harta benda yang diperoleh secara bersama-sama atau sendiri-sendiri selama dalam ikatan perkawinan (Anshary, 2018: 57).

Merujuk pada ketentuan Pasal 35 Ayat (2) Undang-Undang Perkawinan, maka terlihat 
sebelum memasuki perkawinan adakalanya suami atau istri sudah memiliki harta benda bawaan. Dapat saja merupakan harta milik pribadi hasil usaha sendiri, harta keluarganya atau merupakan hasil warisan yang diterima dari orang tuanya. Harta benda yang telah ada sebelum perkawinan ini bila dibawa ke dalam perkawinan tidak akan berubah statusnya.

Berdasarkan Pasal 89 dan $90 \mathrm{KHI}$, para pihak wajib bertanggung jawab memelihara dan melindungi harta istri atau harta suaminya serta harta milik bersama. Jika harta bawaan itu merupakan hak milik pribadi masing-masing jika terjadi kematian salah satu diantaranya maka yang hidup terlama menjadi ahli waris dari si mati. Kalau harta bawaan itu bukan hak miliknya maka kembali sebagai mana adanya sebelumnya. Kalau keduanya meninggal maka ahli waris mereka adalah anak-anaknya.

Mengacu pada Pasal 35 ayat (2) Undang-Undang Perkawinan menetapkan bahwa harta benda yang diperoleh selama dalam perkawinan menjadi harta benda milik bersama. Harta bersama dapat berupa benda berwujud atau benda tak berwujud, baik yang telah ada maupun yang akan ada, kemudian hadiah, honor, penghargaan dan sebagainya yang diperoleh masing-masing pihak yang menyebabkan bertambahnya pendapatan yang ada hubungannya dengan profesi atau pekerjaan sehari-hari suami atau istri menjadi harta milik bersama.

Kedudukan harta dalam perkawinan yang telah diatur dalam Undang-Undang Perkawinan diperkuat dalam KHI, sebagaimana diuraikan dalam Pasal 1 huruf $\mathrm{f} \mathrm{KHI}$ bahwa semua harta yang diperoleh sepasang suami istri selama dalam perkawinan menjadi harta benda kepunyaan bersama, baik harta tersebut diperoleh sendiri-sendiri atau bersama-sama tanpa mempersoalkan terdaftar atau diperoleh atas nama siapa.

Mengenai harta yang diperoleh oleh suami istri selama dalam ikatan perkawinan adalah harta milik bersama, baik masingmasing bekerja pada satu tempat yang sama maupun pada tempat yang berbeda-beda, baik pendapatan itu terdaftar sebagai penghasilan istri atau suami, juga penyimpanannya didaftarkan sebagai simpanan suami atau istri tidak dipersoalkan, baik yang punya pendapatan itu suami saja atau istri saja, atau keduanya mempunyai penghasilan tersendiri selama dalam perkawian. Harta bersama tidak boleh terpisah atau dibagi-bagi selama dalam perkawinan masih berlangsung. Apabila suami istri itu berpisah akibat kematian atau akibat perceraian barulah dapat dibagi. Jika pasangan suami istri itu waktu bercerai atau salah satunya meninggal tidak memiliki anak, maka semua harta besama itu dibagi dua setelah dikeluarkan biaya pemakamam dan pembayar hutanghutang suami istri. Jika pasangan ini mempunyai anak maka yang menjadi ahli waris adalah suami atau istri yang hidup terlama beserta anak-anak mereka.

\section{c. Kewajiban Suami Setelah Bercerai}

Kewajiban Suami istri yang telah resmi bercerai masih mempunyai hak dan kewajiban masing-masing, yaitu:

1. Kewajiban Suami

Pasal 41 UU No. 1 Tahun 1974 tentang Perkawinan menyatakan: Akibat putusnya perkawinan karena perceraian ialah:

a. Baik ibu atau bapak tetap berkewajiban memelihara dan mendidik anakanaknya, semata-mata berdasarkan kepentingan anak; bilamana ada perselisihan mengenai penguasaan anak-anak, Pengadilan memberi keputusannya;

b. Bapak yang bertanggung-jawab atas semua biaya pemeliharaan dan pendidikan yang diperlukan anak itu; bilamana bapak dalam kenyataan tidak dapat memenuhi kewajiban tersebut, Pengadilan dapat menentukan bahwa ibu ikut memikul biaya tersebut.

Perhatikan ketentuan Pasal 41 huruf (b) UU No. 1 Tahun 1974 tentang Perkawinan, berdasarkan ketentuan tersebut diatas dapat diartikan bahwasanya tuntutan perceraian dengan tuntutan pemenuhan nafkah anak adalah 2 hal yang berbeda jadi, bisa saja tuntutan pemenuhan nafkah anak diajukan terpisah dari tuntutan cerai.

Ketentuan ini sejalan dengan UndangUndang No. 23 Tahun 2002 tentang Perlindungan Anak. Dalam Pasal 26 ayat (1) UU No. 23/ 2002 ditegaskan, Orang tua berkewajiban dan bertanggung jawab untuk :

a. Mengasuh, memelihara, mendidik, dan melindungi anak;

b. Menumbuh kembangkan anak sesuai dengan kemampuan, bakat, dan minatnya; dan

c. Mencegah terjadinya perkawinan pada usia anak-anak.

Pasal 30 menyebutkan : bahwa dalam hal orang tua sebagaimana dimaksud dalam Pasal 26, melalaikan kewajibannya, terhadapnya dapat dilakukan tindakan pengawasan atau kuasa asuh orang tua dapat dicabut, dan tindakan pengawasan terhadap orang tua atau pencabutan kuasa asuh sebagaimana dimaksud dalam ayat (1) dilakukan melalui penetapan pengadilan. 
Sesuai dengan ketentuan di atas, jelas dan tegas untuk meminta tanggung jawab mantan suami atas pemenuhan nafkah anak harus dilakukan dengan terlebih dahulu mengajukan gugatan mengenai hal tersebut ke Pengadilan.Mengupayakan pemenuhan kewajiban mantan suami untuk memberi nafkah anak bisa juga dilakukan melalui jalur hukum pidana. Untuk hal ini terlebih dahulu harus mengupayakan laporan polisi bahwa mantan suami telah melakukan penelantaran anak. Dalam UU Perlindungan Anak, dikatakan penelantaran anak apabila si orang tua melakukan tindakan atau perbuatan mengabaikan dengan sengaja kewajiban untuk memelihara, merawat, atau mengurus anak sebagaimana mestinya. Dengan tidak memberikan nafkah sudah cukup dikategorikan sebagai penelantaran anak.

Meskipun demikian, sebenarnya perihal harta milik bersama atau yang lebih dikenal dengan istilah gono-gini, adalah urusan rumah tangga. Urusan ini dapat diselesaikan dengan jalan damai melalui musyawarah. Kesepakatan-kesepakatan yang ditetapkan dalam musyawarah itu kemudian menjadi ketetapan yang mengikat dan berlaku serta menjadi hukum yang harus ditaati suami dan istri. Kelonggaran untuk mencari jalan damai ini lebih disukai, sehingga masalah yang terjadi dapat diselesaikan dengan baik, tanpa harus menambah masalah yang dampaknya sangat mungkin akan ikut mempengaruhi hubungan ukhuwwah yang harus dipertahankan, apalagi sampai mempengaruhi hubungan antara orang tua dan anak

Masyarakat di Kecamatan Sekarbela dalam mewujudkan kondisi yang kemungkinan atau yang sudah terjadi dalam perkawinan sampai putusnya ikatan perkawinan ( perceraian) belum mengerti dengan masalah tersebut karena belum pernah adanya sosialisasi dari pemerintah yang terkait,. Masyarakatnya juga tidak mengetahui atau belum memahami bahwa adanya peraturan yang dapat melindungi mereka setelah terjadinya perceraian terutama yang berhubungan dengan masalah utang piutang. Umumnya masyarakat kalau terjadi perceraian terutama pihak perempuannya tidak terlalu memikirkan hak - hak mereka, begitu ada putusan perceraian mereka pulang ke rumah orang tuax dengan membawa apa yang bisa mereka bawa ( pakaian dan beberapa perabot rumah tangga), hal ini disebabkan karena masyarakatnya masih sangat sederhana kehidupannya, Disamping itu kemungkinan hal tersebut karena pengaruh sistem kekerabatan patrilinial ( mengikuti garis keturunan bapak). Jika pihak perempuannya yang menyebabkan terjadinya utang tersebut, maka keluarga pihak laki - laki ( suaminya) yang menanggung utang tersebut dengan menceraikan istrinya), sebaliknya kalau yang membuat utang suami jelas itu adalah tanggung jawabnya,

\section{SIMPULAN DAN SARAN Simpulan}

Tanggung jawab suami dan istri terhadap utang bersama setelah terjadinya perceraian yaitu dibedakan menjadi 2 (dua) yaitu hutang pribadi dan hutang persatuan (utang gemeenschap, yaitu suatu utang untuk keperluan bersama). Untuk suatu hutang pribadi harus dituntut suami atau isteri yang membuat hutang tersebut, sedangkan yang harus disita pertama-tama adalah benda prive (benda pribadi). Akan tetapi, jika suami yang membuat utang, benda pribadi isteri tidak dapat disita, dan begitu pula sebaliknya. Sedangkan untuk utang persatuan, yang pertama-tama harus disita adalah benda gemeenschap (benda bersama) dan apabila tidak mencukupi, maka benda pribadi suami atau isteri yang membuat hutang itu disita pula.Perlindungan hukum terhadap harta bawaan suami atau istri. Apabila harta bersama diterapkan hukum agama atau kepercayaan masing-masing pihak, apakah itu diperluas menjadi terhadap harta bawaan pun diterapkan hukum agama atau kepercayaannya itu, dan terhadap perceraian dapat diterapkan hukumnya masing-masing untuk pembagian harta dalam perkawinan, apakah itu dapat diterapkan untuk putusnya perkawinan karena kematian atau atas keputusan pengadilan. bukankah substansi ketiganya adalah sama, yaitu memutuskan tali perkawinan, sementara perbedaannya, hanyalah pada pihak yang berhak menerima bagian harta perkawinan itu, yaitu dalam hal perceraian adalah masingmasing pihak, sementara dalam kematian adalah salah satu pihak dan ahli warisnya. Masyarakat di Kecamatan Sekarbela dalam mewujudkan kondisi yang kemungkinan atau yang sudah terjadi dalam perkawinan sampai putusnya ikatan perkawinan (perceraian) belum mengerti dengan masalah tersebut karena belum pernah adanya sosialisasi dari pemerintah yang terkait. Masyarakatnya juga tidak mengetahui atau belum memahami bahwa adanya peraturan yang dapat melindungi mereka setelah terjadinya perceraian terutama yang berhubungan dengan masalah utang piutang. Umumnya masyarakat kalau terjadi perceraian terutama pihak perempuannya tidak terlalu memikirkan hak - hak mereka. Begitu ada putusan perceraian mereka pulang ke rumah orang tuax dengan membawa apa yang bisa mereka bawa 
(pakaian dan beberapa perabot rumah tangga), hal ini disebabkan karena masyarakatnya masih sangat sederhana kehidupannya, Disamping itu kemungkinan hal tersebut karena pengaruh sistem kekerabatan patrilinial ( mengikuti garis keturunan bapak). Jika pihak perempuannya yang menyebabkan terjadinya utang tersebut, maka keluarga pihak laki - laki (suaminya) yang menanggung utang tersebut dengan menceraikan istrinya), sebaliknya kalau yang membuat utang suami jelas itu adalah tanggung jawabnya,

\section{Saran}

Berdasarkan kesimpulan di atas, maka dapat disarakan sebagai berikut: 1). Bagi pemerintah, diharapkan dijadikan sebagai rujukan dalam membuat keputusan bagi penegak hukum, pelaksana Undang-Undang, maupun masyarakat luas, 2). Bagi masyarakat, sebagai sumber informasi dan pengetahuan yang belum mengenal akan hukum tentang suami dan istri terhadap utang bersama setelah terjadinya perceraian.

\section{DAFTAR RUJUKAN}

Anshary. (2019). Hukum Perkawinan di Indonesia. Yogyakarta : Pustaka Pelajar

Hadikusumo, Hilman. (2013). Hukum Perkawinan Indonesia Menurut Perundang undangan, $\mathrm{H}$ Adat, Hukum Agama. Bandung : Mandar Maju

http:// Pendidikan blogspot co.id/ 2021/05/Pencatatan - Perkawinan dan akta - nikah. Html.

Republik Indonesia. (1974). Undang Undang No 1 Tahun 1974 tentang Perkawinan

Republik Indonesia. (2004). Undang Undang No 37 Tahun 2004 tentang Kepailitan

Republik Indonesia. (2019). Undang Undang No 16 Tahun 2019 tentang Perubahan Undang Undang No 1 Tahun 1974

Republik Indonesia. Kitab Undang Undang Hukum Perdata

Republik Indonesia. (2002). Undang-Undang No. 23 Tahun 2002 tentang Perlindungan Anak.

Instruksi Presiden No 1 Tahun 1991 tentang Penyebarluasan Kompilasi Hukum Islam 